\title{
Regulating bodies: the moral panic of child sexuality in the digital era*
}

\section{Zusammenfassung}

Mit zunehmendem Zugang zum Internet hat sich das explorative Verhalten von Kindern zu Sexualität auch auf den Onlinebereich ausgeweitet. Dies führte zu einer Wiederbelebung der moralischen Panik rund um die kindliche Sexualität, insbesondere in Bezug auf das wachsende Phänomen des einvernehmlichen ,, Sextings " zwischen Minderjährigen. Diese moralische Panik wird durch die Sorge um sexuellen Missbrauch und sexuelle Ausbeutung von Kindern im Kontext von „Kinderpornographie“ noch weiter befeuert. In dem Bestreben, Kinder vor solchen Straftaten zu schützen, wird einvernehmliches ,Sexting“ zwischen Minderjährigen in manchen Ländern als Produktion und Verbreitung von „Kinderpornographie“ gewertet und führt so zur Strafverfolgung beteiligter Kinder als SexualstraftäterInnen. Das Recht auf Schutz vor sexuellem Missbrauch und Ausbeutung ist hier das dominierende Narrativ. Dieser Artikel argumentiert, dass die Kriminalisierung von Kindern aufgrund einvernehmlicher sexueller Erkundungen im Online-Raum kontraproduktiv für das Ziel des Kinderschutzes ist. Stattdessen sollten Länder in Fällen von einvernehmlichen „Sexting“ zwischen Minderjährigen einen auf Rechten basierenden Ansatz verfolgen und die widerstreitenden Interessen von Autonomie und Kinderschutz dadurch ausgleichen, dass sie das einvernehmliche „Sexting“ zwischen Minderjährigen aus dem Geltungsbereich der „Kinderpornografie“ ausschließen.

\section{Résumé}

L'élargissement de l'accès à Internet a amplifié l'exploration en ligne par les enfants du terrain de la sexualité. La panique morale concernant la sexualité des enfants connait ainsi un regain d'activité, tout particulièrement au regard du phénomène croissant du "sexting" entre mineur(e)s. Cette panique morale est de plus attisée par les préoccupations concernant les abus et l'exploitation sexuels des enfants dans le cadre des infractions liées à la "pornographie enfantine". Dans une tentative de protection de l'enfant, certains pays ont décidé d'assimiler le "sexting" consensuel entre mineur(e)s à la production et divulgation de "pornographie enfantine," ce qui peut conduire à la poursuite pénale des enfants concerné(e)s en tant que délinquant(e)s sexuel(le)s. Il est ici question de faire primer le droit de l'enfant à être protégé(e) contre l'abus et l'exploitation sexuels. L'article suivant défend l'argumentation selon laquel-

* Sabine K. Witting is a researcher and PhD candidate at University Leiden, Netherlands, and connected to the Department of Child Law and the Centre for Law and Digital Technologies (eLaw). The title of her research is: 'Child sexual abuse in the digital era - Rethinking legal frameworks and transnational law enforcement collaboration'. 
le la criminalisation des enfants pour exploration consensuelle en ligne du territoire de la sexualité, dans un but de la protection de l'enfance, s'avère contreproductive. Pour ces cas de "sexting" consensuel entre mineur(e)s, les États devraient plutôt rechercher un angle d'approche basé sur les droits et tendre à un équilibre entre les intérêts contradictoires de l'autonomie et de la protection de l'enfant, ce qui impose d'exclure le "sexting" consensuel entre mineur(e)s du domaine d'application de la pornographie enfantine.

\section{Introduction}

The regulation of sexual offences is the regulation of bodies. What is considered sexually 'deviant', which practices and preferences cross the line to the socially acceptable, which body enjoys which degree of sexual autonomy - sexual offences are infiltrated by society's understanding of normative sexuality. ${ }^{1}$ Or speaking with Butler: 'regulation of gender has always been part of the work of heterosexist normativity'. ${ }^{2}$ In the same way as society, sexual offences have been developing over time. A good example for this development is the criminal offence of 'sodomy', which originally criminalised a wide range of non-procreative sexual activity, including oral sex, same-sex sexual activity or masturbation. ${ }^{3}$ Regardless of the use of force or abusive authority, any non-procreative sexual activity was considered a criminal offence. The meaning of sodomy has changed in the last decades, focusing on men having sex with men, while decriminalising non-procreative sexual activity between heterosexual partners. And even sodomy laws in the current form are under development, with India being the latest country to declare its sodomy laws unconstitutional. ${ }^{4}$

However, the sexual offences discourse has been until today hampered by a misunderstanding of intimacy and sexualised violence, which becomes obvious with regards to the criminalisation of sodomy and the de-criminalisation of rape within marriages. ${ }^{5}$ It shows that on the one hand, consensual sexual activity between same-sex partners is criminalised, simply because it is perceived as sexually deviant intimacy and harmful to society as a whole. On the other hand, non-consensual sexual activity within a marriage is not criminalised, as it is based on the oppression of the female body and hence socially acceptable.

1 Joachim Renzikowski, Primat des Einverständnisses? Unerwünschte konsensuelle Sexualitäten, in: Ulrike Lembke (edit.), Regulierungen des Intimen. Sexualität und Recht im modernen Staat, Wiesbaden 2017, p. 198.

2 Judith Butler, Undoing Gender, New York 2004, p. 186.

3 Katherine Crawford, European Sexualities 1400 - 1800, Cambridge 2007, p. 156.

4 Kanad Bagchi, Decriminalising Homosexuality in India as a Matter of Transformative Constitutionalism, VerfBlog, 9 September 2018, https://verfassungsblog.de/decriminalising-homosexuality-in-india-as-a-matter-of-transformative-constitutionalism/ [Accessed 3 October 2018]; Gautam Bhatia, Section 377 Referred to a Constitution Bench: Some Issues, Indian Constitutional Law and Philosophy, 8 January 2018, https://indconlawphil.wordpress.com/ 2018/01/08/section-377-referred-to-a-constitution-bench-some-issues/ [Accessed 3 October 2018].

5 Ulrike Lembke, Sexualität und Recht: Eine Einführung, in Ulrike Lembke (edit.), Regulierungen des Intimen. Sexualität und Recht im modernen Staat, Wiesbaden 2017, p. 5. 
Another contested area of sexual rights concerns the sexuality of children. ${ }^{6}$ While the age of consent to sexual activity differs greatly around the world, the most common age of consent is set at 16 to 18 years. ${ }^{7}$ It has to be noted, however, that the age of consent varies greatly between boys and girls, as well as hetero- and homosexual children. ${ }^{8}$ While the regulation of a minimum age of consent to sexual activities aims to protect children from sexual abuse and exploitation by adults, ${ }^{9}$ it can create legal challenges regarding consensual sexual activities between children. As sexual exploration, ranging from hugging to kissing to sexual intercourse, is part of the normal sexual development of teenagers, the age of consent law is at risk of criminalising consensual sexual activities between minors. ${ }^{10}$ As the laws which aim to protect children should not punish them for developmentally normal sexual activity, many countries enacted so-called Romeo-and-Juliet clauses, which - dependent on the country context - exempt sexual activity between teenagers from prosecution, if the partners are not more than two or three years in age apart. ${ }^{11}$ This age gap is considered close enough to minimise the risk of abuse of power or authority of the older partner, and to ensure that both partners can make an informed and autonomous decision on whether to engage in sexual activity.

While contact sexual activity between children is nowadays widely acknowledged within the above-mentioned framework, the sexual exploration of children through the use of information and communication technologies has revived the moral panic around child sexuality. Children and adolescents below the age of 18 years constitute one third of internet users worldwide. ${ }^{12}$ In 104 countries, more than $80 \%$ of the youth

6 Arguing that child sexuality has always been an indicator and an instrument to manage the moral health of a nation, Murray Lee/Thomas Crofts/Michael Salter/ Sanja Milivojevic/ Alyce McGovern, 'Let's Get Sexting': Risk, Power, Sex and Criminalisation in the Moral Domain, International Journal for Crime and Justice, Volume 2 (2013), p. 41; highlighting that the 'idealized concept of the heterosexual nuclear family is at the core' of the age of consent debate in Canada, Carol L. Dauda, Sex, Gender, and Generation: Age of Consent and Moral Regulation in Canada, Politics \& Policy, Volume 38 (2010), p. 1161.

7 SRHR Africa Trust (SAT), TrustLaw, Arnold \& Porter Kaye Scholer LLP, Age of Consent: Global Legal Review, 2017, p. 12; arguing that statutory rape laws did not aim to protect children from forced sexual activity, but were primarily designed to protect a girl's virginity, Henry F. Fradella/Jennifer M. Summer, Sex, Sexuality, Law and (In)Justice, New York 2016, p. 201.

8 SRHR Africa Trust (SAT), TrustLaw, Arnold \& Porter Kaye Scholer LLP, Age of Consent: Global Legal Review, 2017, p. 12

9 Belinda Carpenter/Erin O'Brien/Sharon Hayes/Jodi Death, Harm, Responsibility, Age, and Consent, New Criminal Law Review: An International and Interdisciplinary Journal, Vol. 17 (2014), p. 27.

10 A good example here is the previous South African legislation, which criminalised all forms of sexual interaction with children below the age of 16 years in most circumstances, and has been declared unconstitutional in 2015, see Teddy Bear Clinic for Abused Children and Another v Minister of Justice and Constitutional Development and Another, [2013] ZACC 35, further discussed in IV. A.

11 Fradella/Summer, Sex, Sexuality, Law and (In)Justice (2016), p. 202; Carpenter/ O'Brien/ Hayes/Death, Harm, Responsibility, Age, and Consent, New Criminal Law Review: An International and Interdisciplinary Journal, pp. $36-37$.

12 UNICEF, The State of the World's Children 2017, New York 2017, p. 1. 
population are online. ${ }^{13}$ In so-called 'developed' countries, 94\% of young people aged 15-24 use the internet compared with 67\% in 'developing' countries and only $30 \%$ in 'Least Developed' Countries. ${ }^{14}$ It is therefore not surprising that sexual exploration has expanded to the internet. ${ }^{15}$ A common form of such online sexual exploration is 'sexting'. The term is a portmanteau of the words 'sex' and 'texting' and describes self-produced sexually suggestive or explicit images and texts and distribution thereof by cell phone messaging, internet messenger, social networks et al. ${ }^{16}$ Further, there is a distinction between 'primary sexting', which describes material produced and possessed with the consent of the depicted person(s), and 'secondary' sexting, which describes the further dissemination of such material without the consent of the depicted person. ${ }^{17}$ Apart from such (at least initially) consensually produced and shared material between teenagers, there is a massive amount of so-called 'child pornography' 18 available online, depicting the sexual abuse and exploitation of children in all age groups. ${ }^{19}$ With teenage sexting material and child pornography objectively depicting the same behaviour, i.e. sexual activity involving a minor, the law in most countries does not differentiate under which circumstances the material was produced, but criminalises the production, dissemination and possession of both groups of materials as child pornography offences. As 'primary' sexting material is produced

13 ITU, ICT Facts and Figures in 2017, https://www.itu.int/en/ITU-D/Statistics/Documents/ facts/ICTFactsFigures2017.pdf [Accessed 3 October 2018].

14 Ibid.

15 Jane Bailey/ Hanna Mouna, The Gendered Dimensions of Sexting: Assessing the Applicability of Canada's Child Pornography Provision, Canadian Journal of Women and the Law, Vol. 23 (2011), p. 413.

16 UNICEF, Regulation of Child Online Sexual Abuse. Legal Analysis of International Law \& Comparative Legal Analysis, Windhoek 2016, p. 16.

17 UNICEF, Regulation of Child Online Sexual Abuse. Legal Analysis of International Law \& Comparative Legal Analysis, Windhoek 2016, pp. 37 - 38.

18 The term 'child pornography' has been widely criticised as it is deemed to sugar-coat the abusive and exploitative character of the material, see Sabine K. Witting, The "Greyscale" of "Child Pornography": Of Mangas, Avatars and School Girls: Part 1, Computer and Telecommunications Law Review, Issue 3 (2018), p. 61: "Globally there is a debate over the term "child pornography" as opposed to the more broadly accepted term "child abuse material" (UNODC, Study on the Effects of New Information Technologies on the Abuse of Children (2015), p.8). "Child pornography" may create the impression that "pornography" and "child pornography" are closely related, and hence implies that the child could give consent to "child pornography" (see Maud de Boer-Buquicchio, Report of the Special Rapporteur on the Sale of Children, Child Prostitution and Child Pornography, A/HRC/ $28 / 56$ (2014), para. 29). Nevertheless, in the legal context the term "child pornography" is still prevalent and will therefore be used throughout this article (see UNODC, Comprehensive Study on Cybercrime Draft-February 2013 (New York, 2013), p.101: 67\% of the provisions reviewed use the term "child pornography", whereas only $6 \%$ use the term "child abuse material").'.

$1943 \%$ of material analysed by the Internet Watch Foundation, a UK-based NGO combatting child pornography on the internet, depicts children between 11 and 15 years, while $55 \%$ depict children between 0 and 10 years, of which $2 \%$ depict children between 0 and 2 years (Internet Watch Foundation, Annual Report 2017, Cambridge 2017, p. 4, https:// www.iwf.org.uk/sites/default/files/reports/2018-04/IWF\%202017\%20Annual\%20Report \%20for\%20web_0.pdf [Accessed 6 October 2018]). 
and shared with the consent of the depicted person(s), without use of force or abuse of authority, it does not depict the sexual abuse and exploitation of a child. However, there is an inherent risk for sexting material to become more widely available than initially intended. As the depicted person naturally loses control of the material once shared, they rely on the confidentiality and integrity of the receiver. Such trust is often times broken when the relationship ends, and the material is widely circulated to embarrass the former partner. ${ }^{20}$ This risk proves to be a reality when looking at the number of self-produced sexting material available on child pornography websites, which has been increasing over the past couple of years. ${ }^{21}$ In conclusion, the same picture, depending on the context it is available in and depending upon the person who accesses it, can become abusive towards the child, even though the initial production was non-abusive.

This poses the pivotal question to the legislator: due to the inherent risk of abuse and exploitation for self-produced material, should such material be categorised as child pornography from the beginning and hence anyone - irrelevant of the specific context - who produces, disseminates and possesses such material be considered a child pornography offender? Or does the law have to find a way of addressing 'primary' sexting and child pornography differently? This article aims to investigate the criminal response to 'primary' sexting from a comparative perspective, and through a constitutional lens. As the regulation of teenage sexting touches upon core questions of teenage sexuality, the private sphere as well as freedom of expression (II.), this publication portrays how the US, Canada, and Germany, have addressed the topic of teenage sexting (III.), before proposing a solution to this complex question (IV.) and (V.).

\section{O tempora, o mores!: teenage sexuality and digitalisation}

This section provides a more in-depth introduction to the intersection of teenage sexuality in the digital era as well as teenage sexting and child pornography.

\section{A. Teenage sexuality in the digital era}

Key topics, such as sexuality, identity, intimacy, and interpersonal connection are of interest for teenagers in their journey of identity exploration and construction. While these areas have been traditionally explored and constructed in offline interactions

20 Alisdair A. Gillespie, Child Pornography. Law and Policy, London 2011, pp. 31 - 33; UNICEF, The State of the World's Children 2017 (2017), pp. 220 - 221.

21 UK National Crime Agency, National Strategic Assessment of Serious and Organised Crime 2018, London 2018, p. 10; Internet Watch Foundation, Annual Report 2017 (2017), p. 16. 
with the self and others, an increasingly important realm for such activities is the internet. $^{22}$

Online sexual exploration has been an increasingly important component of teenagers' sexuality. It is hereby important to note that online and offline sexual exploration do not co-exist in silos, but are rather interconnected and hence need to be analysed in a holistic manner. ${ }^{23}$ Due to the specific means of interaction in the online space, 'these online behaviors might be similar, exaggerated, or even reversed from their offline counterparts'. ${ }^{24}$ Important factors which, amongst others such as accessibility and affordability of online services, are characteristic for adolescent online behaviour, are disinhibition and self-disclosure. ${ }^{25}$ Being able to interact with others in an (at least perceived) anonymous manner, might lead adolescents towards being much more open, courageous and bold compared to offline face-to-face interactions. Taking into account the important role peer-to-peer exchange plays in building one's sexuality in the adolescence stage, technology is the medium of choice as it makes such exchange nearly effortless. ${ }^{26}$

The various ways in which adolescents explore their sexuality online include, but are not limited to, searching for information about sexuality and sexual health, constructing and presenting a sexual identity, engaging in sexual interactions online, as well as accessing sexually explicit content. ${ }^{27}$ Focusing on sexual interaction with others online, this may include sexualised conversations with others, as well as activities including direct visual interaction via webcams, also including masturbation or other sexual activities. ${ }^{28}$

Similar to contact sexual exploration, digital sexual exploration comes with potential risks for teenagers. These risks can - if not detected and managed properly - turn into harm. However, it has to be acknowledged that sexual exploration, whether in direct contact or through information and communication technology, is in itself not harmful, as it is part of the normal sexual development of children. Digital exploration poses risks for children, such as unwanted dissemination of material, which can potentially, not inevitably - turn into harm. The differentiation between harm and risk is crucial in guiding the debate around teenage sexting. It will be shown in Section III that this differentiation is unfortunately often times blurred.

22 David Smahel/Kaveri Subrahmanyam, Adolescent Sexuality on the Internet: A Developmental Perspective in: Fabian M. Saleh/Albert J. Grudzinskas/Abigail M. Judge, Adolescent sexual behavior in the digital era, Oxford 2014, p. 62.

23 Smahel/Subrahmanyam, Adolescent Sexuality on the Internet: A Developmental Perspective in: Saleh/ Grudzinskas/Judge, Adolescent sexual behavior in the digital era (2014), p. 63.

24 Ibid.

25 Ibid.

26 April Gile Thomas/Elizabeth Cauffman, Youth Sexting as Child Pornography? Developmental Science Supports Less Harsh Sanctions for Juvenile Sexters, New Criminal Law Review: An International and Interdisciplinary Journal, Vol. 17 (2014), p. 642.

27 Smahel/Subrahmanyam, Adolescent Sexuality on the Internet: A Developmental Perspective in: Saleh/ Grudzinskas/Judge, Adolescent sexual behavior in the digital era (2014), p. 65.

28 Ibid., p. 71. 


\section{B. Child pornography and teenage sexting - two sides of the same coin?}

In order to understand the difficulties around child pornography and teenage sexting, it is crucial to firstly elaborate on the legislative content of child pornography offences, before engaging in the discourse of its relationship to teenage sexting.

Before elaborating on the various elements of child pornography offences, it is crucial to understand the impact of child pornography offences on the victim. Material depicting the sexual abuse and exploitation of children does not only cause significant physical and psychological harm to the depicted child during the production, but also re-traumatises the child every time the material is accessed or shared. Victims of child pornography offences oftentimes face great difficulties in 'closing the chapter', as they are continuously exposed to abuse and exploitation through the circulation of their material. ${ }^{29}$ They might live in a constant state of anxiety, whether and when the material will surface again, and that someone will recognise or expose them. ${ }^{30}$ It is therefore not surprising that the national legislations impose harsh sentences on the production, dissemination, or possession of such material.

With regards to the definition of the term 'child pornography', it has to be noted that it varies greatly between national legislations and within international law. However, most child pornography provisions generally have three elements in common: material, subject and conduct. ${ }^{31}$ While criminalised material covers text, audio and/or visuals, the subject can include actual children, persons who are made to appear as minors and/or virtual child pornography. ${ }^{32}$ The criminalised conduct ranges from production, dissemination and possession to the mere accessing of such material. ${ }^{33}$ For example, Art 2 of the Optional Protocol to the Convention on the Rights of the Child on the sale of children, child prostitution and child pornography (hereafter OPSC), ${ }^{34}$ defines child pornography as 'any representation, by whatever means, of a child in re-

29 Najat M'jid Maalla, Report of the Special Rapporteur on the sale of children, child prostitution and child pornography, 07/2009 (UN Doc. A/HCR/12/23), p. 10 et seq.; ITU, Guidelines for Policy Makers on Child Online Protection, 2009, p. 19; Gillespie, Child Pornography. Law and Policy (2011), pp. 31 - 33; UNICEF, The State of the World's Children 2017, New York 2017, p. 76.

30 Ateret Gewirtz-Meydana/Wendy Walsha/Janis Wolaka/David Finkelhora, The complex experience of child pornography survivors, Child Abuse and Neglect, Volume 80 (2018), p. 244.

31 UNICEF, Regulation of Child Online Sexual Abuse. Legal Analysis of International Law \& Comparative Legal Analysis (2016), p. 32.

32 For an in-depth discussion on virtual child pornography from a comparative perspective, see Sabine K. Witting, The "Greyscale" of "Child Pornography": Of Mangas, Avatars and School Girls: Part 1, Computer and Telecommunications Law Review, p. 61 et seq.; and Sabine K. Witting, The "Greyscale" of "Child Pornography": Of Mangas, Avatars and School Girls: Part 2, Computer and Telecommunications Law Review, Issue 4 (2018), p. 73 et seq.

33 For a comparative analysis of child pornography legislation from Botswana, South Africa, the Philippines, Uganda, Germany and Canada, see UNICEF, Regulation of Child Online Sexual Abuse. Legal Analysis of International Law \& Comparative Legal Analysis (2016).

34 Adopted on 25 May 2000 and entered into force on 18 January 2002. 
al or simulated sexual activities or any representation of the sexual parts of a child for primarily sexual purposes'. As for the material, the OPSC covers both visual and nonvisual material, but with regards to the subject, does not include persons who are made to appear as minors and virtual child pornography. ${ }^{35}$ In contrast, the Council of Europe Convention on Cybercrime ('Budapest Convention'), ${ }^{36}$ defines the term as 'pornographic material that visually depicts a) a minor engaged in sexually explicit conduct, b) a person appearing to be a minor engaging in sexually explicit conduct, c) realistic images representing a minor engaged in sexually explicit conduct.' It therefore excludes all non-visual materials, such as text and audio, but expands the provision to not only cover actual children, but also persons made to appear as minors as well as virtual child pornography. ${ }^{37}$ This shows that even on international level, the term 'child pornography' is not defined in a consistent manner.

However, most child pornography provisions have one element in common, i.e. that the consent of the depicted child is always considered invalid and hence lack of consent is not a relevant element of child pornography offences. The rationale behind this approach is twofold. Firstly, the perceived consent of the child should not be a valid defence in court for the perpetrator. It is a common misperception that all child pornography depicts use of force or violence, and that the child victim always looks distressed, is in pain or crying. However, such material does not always depict 'obvious', 'visual' harm to the child. ${ }^{38}$ Children might be depicted as if they enjoy or are at least compliant with the sexual activity. This is however rather a result of a grooming process or the child's way of accepting the abuse, than an expression of informed consent. Therefore, the mere expression or conduct of the child does not give any further information on the child's actual level of consent. Secondly, and even more importantly, child pornography provisions seem to operate on the presumption that the depicted act is unlawful anyway, and hence there is no reason to consider the consent of the child if he or she could not consent to the depicted act in the first place.

While this might be true for the vast majority of material, it is indeed more complex for the self-generated material discussed in this publication. How this fundamental difference causes a contradiction within the legal system, will be discussed in the next sections.

\section{Teenage sexting across the world: USA, Canada, Germany}

This section describes and discusses the approach to teenage sexting and child pornography in the US, Canada, and Germany. While the US's approach to strictly subsume

35 Maud de Boer-Buquicchio, Report of the Special Rapporteur on the Sale of Children, Child Prostitution and Child Pornography, A/HRC/28/56 (2014), para. 26; UNICEF, Regulation of Child Online Sexual Abuse. Legal Analysis of International Law \& Comparative Legal Analysis (2016), p. 12.

36 Adopted on 8 November 2001, entered into force on 1 July 2004.

37 Council of Europe, Explanatory Report to the Convention on Cybercrime, European Treaty Series - No. 185, Budapest 2001, para. 101; UNICEF, Regulation of Child Online Sexual Abuse. Legal Analysis of International Law \& Comparative Legal Analysis (2016), p. 14.

38 Gillespie, Child Pornography. Law and Policy (2011), pp. 22-23. 
sexting under child pornography might have changed in 2010, Canada describes teenage sexting in a landmark Supreme Court decision on child pornography as an area which raises constitutional concerns if such behaviour is criminalised. Germany, in recent law reforms, has incorporated an exemption clause in its juvenile pornography provision, aligning it with European frameworks on child pornography.

\section{A. USA: non-protected speech in the name of child protection}

As for the broader regulation of 'child pornography', three Supreme Court decisions, namely, Miller vs. California, 413 U.S. 15 (1973), New York v. Ferber, 458 U.S. 747 (1982) and United States v. Stevens, 559 U.S. 460 (2010) set the framework in which the constitutionality of the criminalisation of sexting between minors has to be discussed.

\section{Miller vs. California, 413 U.S. 15 (1973)}

In Miller vs. California, 413 U.S. 15 (1973), the Court held that lewd and obscene speech does not receive First Amendment protection because obscenity serves no crucial role in the exposition of ideas and has little social value. In order to be considered 'obscene', the work as a whole must appeal to the prurient interest, must be patently offensive in light of community standards, and lack serious literary, artistic, political, or scientific value ${ }^{39}$ In line with this approach, many states in the US drafted child pornography provisions which included the obscenity of the material as a necessary element of child pornography offences. However, some states, including New York, went further and criminalised 'any performance which includes sexual conduct by a child less than sixteen years of age', regardless of the obscenity of the material in question. 40

\section{New York v. Ferber, 458 U.S. 747 (1982)}

In New York v. Ferber, 458 U.S. 747 (1982), the Court held that child pornography is a category of speech not protected by the constitution ${ }^{41}$ and that such depictions may be prohibited regardless of their obscenity: obscenity has not been considered a necessary criterion when it comes to child pornography provisions. ${ }^{42}$ Firstly, the Court set out that it had a compelling interest in protecting the physical and psychological integrity of minors. ${ }^{43}$ It confirmed that 'the use of children as subjects of pornographic materials is harmful to the physiological, emotional, and mental health of the

39 Miller vs. California 413 U.S. 15 (1973), at 24.

40 Frederick Schauer, Codifying the First Amendment: New York v. Ferber, College of William and Mary Law School. Faculty Publications, 1982, p. 290.

41 New York vs. Ferber, 458 U.S. 747 (1982), at 764.

42 New York vs. Ferber, 458 U.S. 747 (1982), at 747.

43 New York vs. Ferber, 458 U.S. 747 (1982), at 757. 
child' ${ }^{44}$ Further, the production of child pornography material is 'intrinsically related to the sexual abuse of children [...], [T] he materials produced are a permanent record of the children's participation and the harm to the child is exacerbated by their circulation'. ${ }^{45}$ Their artistic value is to be considered 'modest, if not de minimis' ${ }^{46}$

\section{United States v. Stevens, 559 U.S. 460 (2010)}

Today, all states in the US have enacted child pornography legislation, and the federal Sex Offender Registration and Notification Act requires mandatory sex offender registration if the convicted defendant is over the age of fourteen. ${ }^{47}$ Therefore, courts across the country have been faced with the question whether the considerations with regards to 'child pornography' set out in Ferber also cover teenage sexting material. In cases whereby the conduct was confirmed to fall under the definition of child pornography, the legal consequences ranged from diversion, to plea bargaining and convictions. ${ }^{48}$ In the prominent case of $A b . H v$ State 949 So. 2 d 234 (2007), the sixteenyears old A.H., and her seventeen-years old boyfriend J.G.W. were charged as juveniles under the child pornography laws. The charges were based on digital photos A.H. and J.G.W. took of themselves naked and engaged in sexual behaviour. The State alleged that, while the photos were never shown to a third party, A.H. and J.G.W. emailed the photos to another computer from A.H.'s home. A.H. was convicted for 'producing, directing or promoting a photograph or representation that she knew to include the sexual conduct of a child'. ${ }^{49}$

Looking at the arguments put forward in Ferber which justify the exclusion of child pornography from First Amendment protection, it is however arguable whether the intention behind such exclusion is equally applicable to teenage sexting cases. Firstly, there is no evidence that consensual teenage sexting causes physical, emotional or mental harm to the child. ${ }^{50}$ As discussed above, 'sexting' can be considered to form part of a child's sexual exploration using the means of technology. Further, it has to be stressed that in contrast to child pornography material, teenage sexting material does not depict child sexual abuse, but lawful sexual activity. ${ }^{51}$ Unfortunately, this funda-

44 New York vs. Ferber, 458 U.S. 747 (1982), at 758.

45 New York vs. Ferber, 458 U.S. 747 (1982), at 759.

46 New York vs. Ferber, 458 U.S. 747 (1982), at 762.

47 Julia H. McLaughlin, Exploring the First Amendment Rights of Teens in Relationship to Sexting and Censorship, University of Michigan Journal of Law Reform, Volume 45 (2012), p. 320.

48 Joanna R. Lampe, A Victimless Sex Crime: The Case for Decriminalizing Consensual Teen Sexting, University of Michigan Journal of Law Reform, Volume 46 (2013), p. 710.

49 Lampe, A Victimless Sex Crime: The Case for Decriminalizing Consensual Teen Sexting, University of Michigan Journal of Law Reform, pp. 709 - 710; for an in-depth discussion of the case, see Antonio M. Haynes, The Age of Consent: When is Sexting No Longer Speech Integral to Criminal Conduct, Cornell Law Review, Volume 97 (2012), pp. 385 387.

50 McLaughlin, Exploring the First Amendment Rights of Teens in Relationship to Sexting and Censorship, University of Michigan Journal of Law Reform, p. 324.

51 Ibid., p. 324. 
mental difference has been rejected in the Illinois Supreme Court case People $v$. Hollins, 2012 IL 112754, and led to the absurd result that a 32-year old man can legally have sex with his 17-year old girlfriend (age of consent in Illinois is 17 years), but is convicted as child pornography offender because they produced photographic material of the sexual acts. The defendant's argument, that 'he was in the same position as anyone who photographs his or her legal, consenting sex partner [and] [...] it is not reasonable or fair for the legislature to prohibit the sex partners of such people from photographing such otherwise lawful, private, sexual activity', was turned down by the Court. ${ }^{52}$

In the dissenting opinion, two justices argued that the Court in its analysis has failed to consider United States vs Stevens, which, in their opinion, has a significant impact on the assessment of the case at hand. ${ }^{53}$ In United States vs Stevens, the Supreme Court of the United States clarified that the exclusion of child pornography from First Amendment protection is not based on a mere cost-benefit analysis, and that such an analysis is not sufficient for creating new categories of exempted speech. ${ }^{54}$ Rather, the Court argued that Ferber grounded its analysis in a 'previously recognised, long-established category of unprotected speech', ${ }^{55}$ quoting Giboney v. Empire Storage \& Ice Co., 336 U. S. 490, 498 (1949) in Ferber:

'[T]he constitutional freedom for speech and press extends its immunity to speech or writing used as an integral part of conduct in violation of a valid criminal statute'.

Following Stevens, the dissenting opinion in Hollins stressed that Ferber did not create a new category of exception to First Amendment protection for child pornography material, ${ }^{56}$ and hence that child pornography is not exempted from First Amendment protection per se, but only in cases whereby 'the photograph [is] an integral part of conduct in violation of a valid criminal statute' (internal quotation marks omitted). ${ }^{57}$ As Stevens is a binding authority for the Illinois Supreme Court, the dissenting opinion therefore concluded that the material at hand does not constitute child pornography as defined by the Supreme Court in the context of First Amendment considerations. ${ }^{58}$

\section{Assessment}

While the shift from Ferber to Stevens has to be generally welcomed with regards to teenage sexting cases, it might leave a range of material, which does not obviously depict sexual abuse of a child, in a grey area. An example for such material could be sexually suggestive posing material of a child or a depiction of a masturbating child, as nudity or masturbation are per se not criminal offences. Assuming that Stevens did

52 People v. Hollins, 2012 IL 112754, para. 39 - 42.

53 Ibid., para. 47.

54 United States v. Stevens, 559 U.S. 460 (2010), pp. 8 - 9.

55 Ibid., p. 8.

56 People v. Hollins, 2012 IL 112754, para. 67.

57 People v. Hollins, 2012 IL 112754, para. 66.

58 Ibid., para. 68, 70 . 
not intend to preclude such material from the First Amendment exemption, further specification is required in determining which conduct exactly constitutes the sexual abuse: the interaction with the child itself, or photographing a child in a sexualised position. ${ }^{59}$ If the latter is considered the underlying criminal act, ${ }^{60}$ then sexual abuse and speech are one identical act. This line of argument creates the offence 'sexual abuse through the act of photographing', which seems quite artificially constructed.

Regardless of the challenges of the blank interrelation of underlying criminal act and speech, it has to be awaited if the Supreme Court actually goes as far as accepting that age of consent and child pornography provisions need to be stringently aligned to avoid that sexual activity online and offline is treated differently.

\section{B. Canada: Balancing 'right to document' and potential harm to children}

Canada has since 2001 worked on balancing child protection and freedom of expression concerns in sexting cases. Starting off with a private use exception for certain categories of child pornography developed in the landmark decision $R$. v. Sharpe, 2001 SCC 2, [2001] 1 S.C.R. 45, several court decisions have further developed the range of the private use exception.

\section{R. v. Sharpe, 2001 SCC 2, [2001] 1 S.C.R. 45}

In its landmark decision $R$. v. Sharpe, 2001 SCC 2, [2001] 1 S.C.R. 45, the Canadian Supreme Court had to decide whether Canadian law, which criminalises the possession of child pornography, is unconstitutional because it violates freedom of expression as guaranteed under the Canadian Constitution. ${ }^{61}$ The key question therefore was whether Canadian law criminalises the possession of an unjustifiably broad range of child pornography material. ${ }^{62}$ The Court held that the infringement of the accused's right to freedom of expression is justifiable.

First, the Court started by setting out the values at stake: freedom of the expression on the one hand, and prevention of harm to children on the other hand. ${ }^{63}$ It stressed

59 MacKenzie Smith, You Can Touch, But You Can't Look: Examining the Inconsistencies in Our Age of Consent and Child Pornography Laws, Southern California Law Review, Volume 87 (2014), p. 870; in Haynes, The Age of Consent: When is Sexting No Longer Speech Integral to Criminal Conduct, Cornell Law Review, p. 395, Haynes argues that on the basis of Stevens, most teenage sexting activities should enjoy First Amendment protection, because 'neither nudity, masturbation, nor even large amounts of teenage sex are illegal'. However, he fails to acknowledge that a nude child or a child masturbating is also not a criminal offence per se, but it can be assumed there is no intent to also decriminalise the depiction of such sexual activity.

60 Smith, You Can Touch, But You Can't Look: Examining the Inconsistencies in Our Age of Consent and Child Pornography Laws, Southern California Law Review, p. 870.

61 R. v. Sharpe [2001] SCC 2.

62 Ibid., para. 5.

63 Ibid., para. 29. 
that children are in the need of protection from the harmful effects of any form of child sexual abuse and exploitation and should not be considered appropriate sexual partners. ${ }^{64}$ However, the importance of freedom of expression demands a clear legal framework on what constitutes 'child pornography'. ${ }^{65}$ When diving into the exact meaning of the term 'person' as used in section 163.1 of the Canadian Penal Code, the Court stated that 'person' also includes auto-depictions of teenagers, and that teenagers could hence be charged and convicted for taking and keeping photos of themselves engaged in sexual activity. ${ }^{66}$ While the current defence of public good as contained in section 163.1 could theoretically be applied in such cases, by arguing that the public good is served by possessing materials that promote the expressive and psychological wellbeing or enhance one's sexual identity in ways that do not involve any harm to others, the Court noted that such defence might not be sufficient to exclude each case of teenage sexting from the criminal justice system. ${ }^{67}$

Therefore, the Court raised concerns that the current legal framework catches material which is at the centre of a person's self-fulfilment, while posing little to no harm to others. The Court developed two categories of material: firstly, private journals, writings or other works of the imagination, which are created and kept exclusively for oneself, ${ }^{68}$ and secondly, 'privately created visual recordings of lawful sexual activity made by or depicting the person in possession and intended only for private use', ${ }^{69}$ such as teenage sexting material.

In order to determine whether the limitation of freedom of expression imposed by section 163.1 is justified under the constitution, the Court identified the reduction of child exploitation and the prevention of harm to children as pressing and substantial legislative objective. With regards to the proportionality between the limitation to freedom of expression and the benefits of the law, the Court found that there is a rational connection between the law and the pursued purpose, by arguing that - inter alia - child pornography promotes cognitive distortions, fuels fantasies that could incite offenders, or can be used to groom or seduce children. ${ }^{70}$ Further, in order to determine whether the law only minimally impairs freedom of expression, the Court stressed that it suffices if the law is reasonably tailored to its objectives and impairs the concerned right not more than reasonably necessary. ${ }^{71}$ The Court raised that the second category of material as defined previously only presents a small risk of causing harm to children, as the material was initially produced by him- or herself and hence the risk of negative attitudinal changes is not expected to be significant. ${ }^{72}$ Following

64 Ibid., para. 34.

65 Ibid.

66 Ibid., para. $40-41$.

67 Ibid., para. 71.

$68 \mathrm{Ibid}$., para. 75; for an in-depth analysis of the constitutionality of the inclusion of the first category of material, see Witting, The "Greyscale" of "Child Pornography": Of Mangas, Avatars and School Girls: Part 1, Computer and Telecommunications Law Review, and Witting, The "Greyscale" of "Child Pornography": Of Mangas, Avatars and School Girls: Part 2, Computer and Telecommunications Law Review.

69 R. v. Sharpe [2001] SCC 2, para. 76.

70 Ibid., para. 86.

71 Ibid., para. $95-96$.

72 Ibid., para. 100. 
this line of arguments, the law might be overbroad. However, the Court postponed the final determination of this issue to the final stage of the proportionality test, i.e. the final balance. ${ }^{73}$ The Court therefore had to determine whether the benefits of the law in achieving prevention of harm to children outweigh the impact of the law on freedom of expression. ${ }^{74}$ In this context, the law recognised that such material might be relevant for teenagers self-fulfilment, self-actualisation and sexual exploration and identity, and could even assist in building 'loving and respectful relationships through erotic pictures of themselves engaged in sexual activity'. ${ }^{75}$ If such acts were criminalised, the impact on the freedom of expression could not be justified through the potential benefits of the law in preventing harm to children. While overall holding the child pornography provisions contained in section 163.1 constitutional, the Court ruled that in the two previously identified categories, the infringement on the freedom of expression cannot be justified. Particular with regards to teenage sexting, the Court states:

'It further prohibits a teenager from possessing, again exclusively for personal use, sexually explicit photographs or videotapes of him-or herself alone or engaged with a partner in lawful sexual activity. The inclusion of these peripheral materials in the laws' prohibition trenches heavily on freedom of expression while adding little to the protection the law provides children. ${ }^{76}$

Summarising the elements of second category material, the Court states that auto-depictions taken by a child of him- or herself alone, kept in strict privacy and intended for private use only should be excluded. Further, recordings of lawful sexual activity are exempted, if the person possessing the recording has either personally recorded it or participated in the sexual activity, if the sexual activity is lawful, ensuring consent of all parties and precluding abuse or exploitation of the depicted child, and the parties must have further consented to the recording. ${ }^{77}$ These exemptions apply both to the possession as well as the production of such material. ${ }^{78}$

The Court therefore concluded that it upholds section 163.1 of the Criminal Code, but reading two exceptions into it:

(a) The first exception protects the possession of expressive material created through the efforts of a single person and held by that person alone, exclusively for his or her own personal use. This exception protects deeply private expression, such as personal journals and drawings, intended solely for the eyes of their creator.

(b) The second exception protects a person's possession of visual recordings created by or depicting that person, but only where these recordings do not depict unla-

73 Ibid., para. 101.

74 Ibid., para. 102.

75 Ibid., para. 109.

76 Ibid., para. 110.

77 Ibid., para. 116.

78 Ibid., para. 117. 
wful sexual activity, are held only for private use, and were created with the consent of those persons depicted. ${ }^{\prime 79}$

In the dissenting opinion, the justices claimed that the Court had applied a formalistic and rigid approach and not taken the factual and social context into account. ${ }^{80}$ Further, the dissenting opinion stressed that 'the more distant the expression from the core values underlying the right, the more likely action restricting it can be justified' ${ }^{81}$ It stated that with regards to child pornography, the value of the expression is limited, and only pursues basic needs of physical arousal. ${ }^{82}$ The same low level of expression was allocated to teenagers who produce sexually explicit material. Such activities are considered 'harmful self-indulgence supporting unhealthy attitudes towards oneself and others'. ${ }^{83}$ It is argued that authorship and intention are irrelevant when it comes to child pornography if Parliament's pursued objective, i.e. prevent the harm which flows from the very existence of such material, is to be achieved. ${ }^{84}$ Submitting that there does indeed exist a very real harm to teenagers, the dissenting opinion pointed out that it is impossible to determine whether the adolescent depicted in a certain picture has been exploited in its production. ${ }^{85}$ Further, presenting statistics that $30 \%$ of sex offenders in Canada are below the age of 18 years, it is stressed that even auto-depictions by teenagers could be used to groom other children, and hence that such auto-depictions have indeed potential to be used to exploit other children. ${ }^{86}$ In general, society needs to be protective of the state of childhood, which is considered 'as a time, firstly, for the enjoyment of innocence and, then, gradually for the development out of innocence'. ${ }^{87}$ Even though children might have the capacity to legally consent to sexual activity, they are not considered capable of foreseeing the consequences of creating a permanent record of them engaging in such activity. ${ }^{88}$ In conclusion:

'Any deleterious effect on the self-fulfilment of teenagers who produce permanent records of their own sexual activity in an environment of mutual consent is, therefore, by far outweighed by the salutary effects on all children resulting from the prohibition of the possession of child pornography'. 89

Between majority and dissenting opinion, it is clear that the former considers teenage sexting as valuable speech which impacts the final balance in favour of freedom of speech, whereas the latter denies teenage sexting any higher value and hence argues in favour of (perceived) child protection concerns.

79 Ibid., para. 128.

80 Ibid., para. 154.

81 Ibid., para. 181.

82 Ibid., para. 185.

83 Ibid., para. 212.

84 Ibid., para. 215, 217.

85 Ibid., para. 229.

86 Ibid., para. 230.

87 Ibid., para. 231.

88 Ibid.

89 Ibid., para. 238. 


\section{R. v. Dabrowski, 2007 ONCA 619}

The range of the private use exception created in Sharpe has been further specified in Ontario Court of Appeal's R. v. Dabrowski, 2007 ONCA 619. In this case, a 28-yearold man had a sexual relationship with a 14-year-old girl. They decided to videotape some of their sexual activity. When the relationship ended, the accused gave the videotapes to a friend for 'safekeeping', ${ }^{90}$ but allegedly threatened her later to share the videos with her family or put them on a public website. ${ }^{91}$ As the girl initially agreed to the production of the video, the question arose whether in this case the 'private use' exception applied.

Apart from the factual concerns whether the accused indeed made threats to make the material public which would consequently exclude the applicability of the "private use' exemption, the Court had to determine whether the fact that the accused transferred the tape to a third party rendered the 'private use' exemption inapplicable. The Court interpreted the term 'private use' to not equal exclusive possession. Transferring the material to another person such as a lawyer or trusted party for safekeeping would not deactivate the applicability of the 'private use' exemption. ${ }^{92}$ In order to ensure that the exemption is handled with caution, the Court spelled out factors to be considered in order to determine whether giving up exclusive possession resulted in a loss of privacy:

'Questions such as to whom was the material given, what was the purpose or reason for the transfer, what terms or conditions were agreed upon when the material was given up, what control did the accused maintain over the material, was the material in fact viewed by anyone other than the consensual participants, would be relevant, all in the context of the credibility of the accused and others. ${ }^{93}$

In conclusion, the 'private use' exemption is not interpreted in a strict exclusive possession manner, but rather means effective control over the material, which is to be determined according to the factors laid out above.

\section{R. v. Keough, 2011 ABQB 48}

After Dabrowski, the 'private use' exception created in Sharpe has been further developed in the Court of Queen's Bench of Alberta case R. v. Keough, 2011 ABQB 48. In this case, 15-year-old S.C. and 18-year-old M.A. produced of a video of themselves engaged in sexual activity. ${ }^{94}$ With the agreement of S.C., the video, then on a minicassette, was to be turned into a VHS recording. Therefore, M.A. handed the material over to a third person, the accused, who returned the material after the transformation to VHS recording. S.C. and M.A. decided that the VHS should be destroyed afterwards, and M.A. told S.C. he had done so. However, he actually handed the recording

90 R. v. Dabrowski, 2007 ONCA 619, para. 2 - 5.

91 Ibid., para. 11.

92 Ibid., para. $28-29$.

93 Ibid., para. 30.

94 R. v. Keough, 2011 ABQB 48, para. 24 - 30. 
over to the accused (again), for him to destroy it. The accused retained the material and copied the recording. ${ }^{95}$

In this case, the Court had to decide the scope of the private use exception, and conclusively, the scope of the 'right to document' as developed under Sharpe. ${ }^{96}$ As a starting point, the Court spelled out the elements of the private use exemption clause developed in Sharpe as follows:

'This passage provides some characteristics of private use materials:

1. all participants must consent,

2. no exploitation or abuse may be involved,

3. the sexual activity must be lawful,

4. the person in possession must have either:

a) been a participant in the recorded sexual activity, or

b) recorded the sexual activity. ${ }^{97}$

Firstly, the Court considered whether the format change and the copying had the effect of removing the 'private use' exemption. ${ }^{98}$ If the owners of the material continue to exert control over the material, the Court concluded that the private use exemption would still apply. ${ }^{99}$ Even if the accused had viewed the material during the copying process, the situation would be comparable to the accused in persona observing the sexual activity between S.C. and M.A. ${ }^{100}$ As such observation is not illegal as long as all parties consent to it, the viewing of the material is also not illegal. ${ }^{101}$ Keeping in mind that both S.C. and M.A. had consented to the format change, the Court concluded that they also consented to any collateral viewing during the format change process. ${ }^{102}$

However, the fact that the accused continued to have access to the material without the consent of S.C., namely after it was returned to him by M.A. with the instruction to destroy the material, rendered the private use exemption inapplicable in this case. S.C. was clearly under the impression that M.A. had destroyed the material, and hence did not consent to the continuous access by the accused. ${ }^{103}$ Therefore, the Court found the accused guilty of possession of child pornography. ${ }^{104}$

95 Ibid., para. $168-180$.

96 Ibid., para. 196.

97 Ibid., para. 188; please note that the additional element of 'no exploitation or abuse may be involved' in the private use exception has been struck down by the Supreme Court in R. v. Barabash, 2015 SCC 29 (see III. B. IV. below).

98 Ibid., para. 199.

99 Ibid., para. 203.

100 Ibid., para. $207-208$.

101 Ibid., para. 207.

102 Ibid., para. 208.

103 Ibid., para. 210.

104 Ibid., para. 216. 


\section{R. v. Barabash, 2015 SCC 29}

In R. v. Barabash, 2015 SCC 29, the Canadian Supreme Court further developed the interpretation of the Sharpe private use exception, focusing on the element of 'unlawful sexual activity'. In Barabash, two 14-year old girls, who came from troubled family backgrounds, had a history of drug addiction, criminal offences and - in the case of one girl - prostitution, had run away from an adolescent treatment centre and stayed at the 60-year-old accused's residence, which one of the girls at trial described as a stereotypic 'crack house'. Another accused, Barabash's 41-year-old friend, visited frequently and was also involved in drug abuse. During the time the girls stayed at the residence, they were involved in the creation of video recordings of sexual activity and still images with each other and with Barabash's friend, with Barabash operating the camera. Both accused were charged with making child pornography, with Barabash charged additionally with possession of child pornography. ${ }^{105}$

While the trial judge confirmed that the material constitutes child pornography, he held that all elements of the private use exception in Sharpe were met and entered acquittals. ${ }^{106}$ The trial judge's decision was appealed on the grounds that there was an error in the interpretation of the private use exception. The Court of Appeal, relying on R. v. Cockell, 2013 ABCA 112, 553 A.R. 91, held that the private use exception contained additional elements, namely that 'there was no exploitation or abuse involved in the creation of the recording, and a requirement that parties intended the pornographic material to be for the private use of all those involved in its creation' ${ }^{107}$ Therefore, the Court of Appeal held that 'the issue of lawfulness in this context was not limited to whether any specific crime was committed against the children on the video, or in the physical process of making the video. The lawfulness of the activity in the video for the purpose of an exception that protected expressive freedom was activity that did not involve child exploitation or abuse as cognisable in law generally, not just crimes under the Code. ${ }^{108}$

The Supreme Court in Barabash rendered this interpretation of Sharpe incorrect, as exploitative or abusive circumstances are sufficiently covered by the element of lawfulness. As even consensual sexual activity with a child in a relationship of dependency or in a relationship that is exploitative to that child is a criminal offence, regardless of the consent of the child, the Court saw no need for an additional element. ${ }^{109}$ Relevant indicia for an exploitative relationship include the age of the young person and the age difference to the sexual partner, the evolution of the relationship and the de-

105 R. v. Barabash, 2015 SCC 29, para. $4-8$.

106 Ibid., para. 10.

107 Ibid., para. 11.

108 Ibid., para. 36.

109 R. v. Barabash, 2015 SCC 29, para. 34 - 35 quoting section 153. (1) of the Criminal Code [emphasis added]:

153. (1) Every person commits an offence who is in a position of trust or authority towards a young person, who is a person with whom the young person is in a relationship of dependency or who is in a relationship with a young person that is exploitative of the young person, and who

(a) for a sexual purpose, touches, directly or indirectly, with a part of the body or with an object, any part of the body of the young person; or 
gree of control or influence over the young person. ${ }^{110}$ As the elements of an exploitative relationship are, however, assessed with regards to the sexual activity, the Crown argued that there is a need to examine how exploitation may have influenced a young person's consent to being recorded. The Crown submitted that this needs to be assessed separately from the consent to the underlying sexual activity. In the opinion of the Court, this problem can only arise when the underlying sexual activity is not considered unlawful. In the context of Canadian law, this would require a situation where no sexual touching occurs or where the touching is not invited, counselled or incited, for example a nude posing image. The Court notes that in such cases, consent to the sexual activity and to the recording are often times intertwined. Acknowledging that 'an exploitative relationship would be relevant to the common law rules of consent in the context of consent to recording', the Court resumes that such circumstances do not arise in the case at hand and therefore will be left to 'a case with a proper record and argument. The implications might be far reaching'. ${ }^{111}$ Further, the Court struck down an additional element of 'mutuality of benefit', as it cannot be derived from the wording of the private use exception in Sharpe and complicates the private use test while not adding any distinct benefit. ${ }^{112}$ Apart from the above issues around the lawfulness, consent and exploitation, the Court in an obiter dictum stated that the range of the 'solely for private use' requirement as set out in Sharpe has to be interpreted in terms of consent to the ongoing possession. ${ }^{113}$ This means that depicted persons 'retain the ability to ensure its return and destruction'. ${ }^{114}$

Even though the Court struck down the additional element of abuse or exploitation, it held that the trial judge had insufficiently analysed whether the relationship between the girls and the accused was exploitative. In particular, circumstances such as drug addiction, need for shelter, and history of homelessness and prostitution, have to be considered in the present case. ${ }^{115}$ The Court further stressed that the trial judge wrongfully focused on the exploitative character of the activity, rather than the broader relationship. ${ }^{116}$

\section{Assessment}

It is commendable that the Canadian Supreme Court as early as 2001 in Sharpe took a child rights approach to the issue of teenage sexting, stressing the value of the expressed speech, and carefully balancing this right against the potential risk involved. What might be criticised, however, is the inconsistency of the elements applied in the priva-

(b) for a sexual purpose, invites, counsels or incites a young person to touch, directly or indirectly, with a part of the body or with an object, the body of any person, including the body of the person who so invites, counsels or incites and the body of the young person.

110 Ibid., para. 36.

111 Ibid., para. 47 and 48.

112 Ibid., para. 52 and 53.

113 Ibid., para. 29.

114 Ibid., para. 30.

115 Ibid., para. 54 and 55.

116 Ibid., para. 56. 
te use exception. ${ }^{117}$ Taking the most comprehensive list of elements as stated above in Sharpe into account, ${ }^{118}$ the Court has developed an exemption clause which acknowledges a 'right to document', ${ }^{119}$ and carefully balances this right with child protection concerns. Even though it is not precisely specified whether this 'right to document' is rooted in freedom of expression, right to privacy or any other charter right, the child rights perspective to teenage sexting is visionary.

However, the wide interpretation of the exception clause in particular in Dabrowski is of concern. In contrast to Keough, it is important to acknowledge that the material in Dabrowski was from the beginning shared without the consent of the depicted child. Even in that case, the Court accepted that exclusive possession is not required, as long as it can be established that the accused is still in control of the material. While this can be accepted in case of transferring the material to a safety box or a lawyer, it seems disproportional to draw an equal conclusion if the material is transferred to a third party, who is not by contract or by position obliged to act with discretion and integrity. In such a case, the potential harm caused to the depicted child outweighs the freedom of expression aspect raised in Sharpe. The dissemination of the material to a third party without the consent of the depicted child should therefore only fall under the private use exception if the third party has a legitimate interest in the possession and if confidentiality of the material can be maintained.

Apart from the issue of whether the private use exception is applicable in cases where the material is shared with third parties, the Court in Keough made a further remarkable interpretation of the Sharpe exception. In the previous Court of Queen's Bench of Alberta case R. v. Bono, [2008] O.J. No. 3928 (QL), a 14-year old girl recorded herself masturbating and sent the material to the accused. The Court had held that the Sharpe exception clause only applies if the person in possession of the material had either recorded or participated in the sexual activity in question, and hence rendered the private use exception inapplicable in this case. ${ }^{120}$ While this is in line with the wording in Sharpe, the Court in Keough held that such an interpretation would be overtly restrictive, as also such a conduct 'reinforces healthy sexual relationships and self-actualization'. ${ }^{121}$ Therefore, the Court expanded the scope of the private use exception to also include such 'selfie' scenarios.

The Supreme Court's Barabash decision correctly states that with regards to the underlying sexual activity, elements of abuse and exploitation are sufficiently covered by the element of 'lawful sexual activity'. However, the Crown rightfully questions whether - apart from the element of 'consent to recording' - there is a need for asses-

117 Element of consent to production of material is missing in R. v. Sharpe [2001] SCC 2, para. 109.

118 Most comprehensive list contained in R. v. Sharpe [2001] SCC 2, para 116.

119 R. v. Keough, 2011 ABQB 48, para. 196.

120 R. v. Bono, [2008] O.J. No. 3928 (QL), para 24; it has to be noted that in the Court in Bono did not only render the private use exception inapplicable because the accused did not record or participate in the material, but also because he pretended to be a 16-year-old boy while actually being a 52-year old man. As he misrepresented his identity to the victim, the consent of the victim was also considered invalid, which also lead to the inapplicability of the private use exception (R. v. Bono, [2008] O.J. No. 3928 (QL), para. 6, 24).

121 R. v. Keough, 2011 ABQB 48, para. $276-277$. 
sing exploitative circumstances with regards to the recording. Even though the Court leaves this question open intentionally, it can be derived from the deliberations that the Court operates on the basis that sexual activity and recording are so closely intertwined, that only in the case where the sexual activity does not fall under the term 'exploitative relationship' as spelled out in the Criminal Code, a loophole with regards to exploitative recording can occur. The question is therefore: if the recording is consensual but exploitative, does this mean that automatically the sexual activity is also exploitative and hence unlawful, rendering the private use exception inapplicable? Or do cases occur whereby the exploitative element solely refers to the recording? If this is the case, there is indeed a need for an additional element of exploitative relationship with regards to the recording. In the Canadian context, such an additional element either requires that the Supreme Court in amending Sharpe explicitly recognises such an element as it cannot be derived from the wording, or that the Criminal Code's catalogue of offences with regards to sexual activity in an exploitative relationship is expanded. ${ }^{122}$

\section{Germany: modelling European standards in national legislation}

Sections $184 \mathrm{~b}$ and $184 \mathrm{c}$ of the German Criminal Code ${ }^{123}$ broadly criminalise the creation, possession, and dissemination of child sexual abuse material. Germany's Criminal Code differentiates between child pornography (depicted person below the age of 14 years), as stipulated in section $184 \mathrm{~b}$, and juvenile pornography (depicted person 14 years or older, but below the age of 18 years), as stipulated in section $184 \mathrm{c}$. The differentiation between child and juvenile pornography mainly impacts the range of sentence - the definition and the catalogue of offences have been largely aligned. ${ }^{124}$

The regulation of child and juvenile pornography was strongly influenced by the Lanzarote Convention $^{125}$ as well as the Directive 2011/93/EU of 13 December 2011 on combating the sexual abuse and sexual exploitation of children and child pornography (hereafter 'Directive'). ${ }^{126}$ Major changes in the legislative framework with regards to child and juvenile pornography were first enacted in 2008 , followed by an

122 Joshua Sealy-Harrington/Ashton Menuz, Keep It To Yourself: The Private Use Exception for Child Pornography Offences, ABlawg: The University of Calgary Faculty of Law Blog, https://ablawg.ca/2015/06/23/keep-it-to-yourself-the-private-use-exception-forchild-pornography-offences/ [Accessed 21 October 2018].

123 German version of the Penal Code available here: https://www.gesetze-im-internet.de/ $\mathrm{stgb} /$; the official English version of the Penal Code (https://www.gesetze-im-internet.de/ englisch_stgb/) does not contain the recent amendments to section $184 \mathrm{~b}$ and $184 \mathrm{c}$ from 21 January 2015.

124 Tatjana Hörnle, Die Umsetzung des Rahmenbeschlusses zur Bekämpfung der sexuellen Ausbeutung von Kindern und der Kinderpornographie, NJW 2003, p. 3523.

125 Germany signed the Lanzarote Convention on 25 October 2007, and ratified it on 18 November 2015, https://www.coe.int/en/web/conventions/full-list/-/conventions/treaty/201/ signatures?desktop=true [Accessed on 23 October 2018].

126 Accessible here: https://eur-lex.europa.eu/legal-content/EN/TXT/?uri=celex \%3A32011L0093 [Accessed on 23 October 2018]. 
amendment in 2015. As an in-depth discussion of both criminal code amendments exceeds the scope of this publication, the below will focus on the 2015 amendment, in light of the Lanzarote Convention and the Directive.

\section{Council of Europe Convention on the Protection of Children against Sexual Exploitation and Sexual Abuse ('Lanzarote Convention')}

Even though Germany only ratified the Lanzarote Convention on 18 November 2015, the Convention prompted legislative reform in the area of child sexual abuse and exploitation already after its signature on 25 October 2007. ${ }^{127}$ The Lanzarote Convention aims to set a standard for various forms of child sexual abuse and exploitation offences, and enhance international collaboration in the prevention and response to such offences. ${ }^{128}$ In Art 20 (1) and (2), the Convention provides for a broad criminalisation of child pornography offences, responding to recent developments such as child webcam sexual abuse by criminalising the mere accessing of child pornography, without downloading the material. ${ }^{129}$ Further, Art 20 (3) provides member states with an optout mechanism for teenage sexting material. The exemption clause reads as follows:

'Each Party may reserve the right not to apply, in whole or in part, paragraph 1.a and $e$ to the production and possession of pornographic material [...] involving children who have reached the age set in application of Article 18, paragraph 2, where these images are produced and possessed by them with their consent and solely for their own private use.'

Member states hence can make reservations in respect of the criminalisation of the production or possession of images which involve children who have reached the legal age for sexual activities as prescribed in national law, and where the images are produced and possessed by them with their consent and solely for their own private use. ${ }^{130}$ From the wording of the exemption clause, it is apparent that the lawfulness of the underlying sexual activity is not explicitly mentioned. However, as the consent to recording of a sexual activity logically implies the consent to such underlying activity, this is not problematic.

127 BT-Dr 18/2601, p. 1.

128 Susan H. Bitensky, Introductory Note to Council of Europe Convention on the Protection of Children against Sexual Exploitation and Sexual Abuse, International Legal Materials, Vol. 49 (2010), p. 1663.

129 UNODC, Study on the Effects of New Information Technologies on the Abuse of Children (2015), pp. 22 - 23; Council of Europe, Explanatory Report to the Convention on Cybercrime, European Treaty Series - No. 185, Budapest 2001, para. 140.

130 Council of Europe, Explanatory Report to the Convention on Cybercrime, European Treaty Series - No. 185, Budapest 2001, para. 144. 


\section{Directive 2011/93/EU of 13 December 2011}

The Directive was precedented by the EU framework decision 2004/68/JHA of 22 December 2003 (hereafter: 'framework decision'). ${ }^{131}$ The framework decision aimed to ensure that serious criminal offences such as the sexual exploitation of children and child pornography are addressed in a comprehensive manner with standardised constituent elements of criminal law. ${ }^{132}$ Acknowledging that the framework decision only criminalised a limited number of offences, did not sufficiently address new forms of abuse and exploitation using information technology, and did not sufficiently provide for instruments facilitating transnational law enforcement collaboration, the EU Commission in 2009 submitted a proposal for a new framework decision, ${ }^{133}$ which aimed to repeal and incorporate the 2003 framework decision. ${ }^{134}$ Apart from broadly criminalising child pornography offences in Art 5, the Directive in its Art 8 (3) provides for an optional exemption clause for various consensual activities. With regards to child pornography, it states:

'It shall be within the discretion of Member States to decide whether Article 5(2) [acquisition or possession] and (6) apply to the production, acquisition or possession of material involving children who have reached the age of sexual consent where that material is produced and possessed with the consent of those children

131 Framework Decisions can best be compared with the legal instrument of a Directive. Both instruments are binding upon Member States as to the result to be achieved but leave the choice of form and method for implementation to the national authorities.

132 EU framework decision 2004/68/JHA of 22 December 2003, para. 7; Apart from criminalising - inter alia - the production, dissemination and possession of child pornography material, the framework allowed member states to exclude certain conduct related to child pornography, in particular providing the option to exempting teenage sexting from the applicability of the child pornography provision. In Art 3 (2) (b), the framework states:

"A Member State may exclude from criminal liability conduct relating to child pornography:

[...] (b) referred to in Article 1(b)(i) and (ii) where, in the case of production and possession, images of children having reached the age of sexual consent are produced and possessed with their consent and solely for their own private use. Even where the existence of consent has been established, it shall not be considered valid, if for example superior age, maturity, position, status, experience or the victim's dependency on the perpetrator has been abused in achieving the consent;' [...]

While the framework decision judging from its wording seems to be modelled after Shar$p e$, it is not clear whether the additional indicators for an exploitative situation apply to the consent to the sexual activity, the recording or both.

133 Under the 1997 Treaty of Amsterdam, framework decisions were binding upon the Member States as to the result to be achieved but shall leave to the national authorities the choice of form and methods. This instrument was repealed by the 2009 Lisbon Treaty, which established the instrument of directives. Directives are binding, as to the result to be achieved, upon any or all of the Member States to whom they are addressed but leave the choice of form and methods to the national authorities.

134 Commission of the European Communities, Proposal for a Council Framework Decision on combating the sexual abuse, sexual exploitation of children and child pornography, repealing Framework Decision 2004/68/JHA, 2009/0049 (CNS), pp. 3, 6. 
and only for the private use of the persons involved, in so far as the acts did not involve any abuse.'

Firstly, it has to be noted that the Directive exempts not only production and possession of such material, but also acquisition. This term causes a contradiction within the exemption clause, as the term 'acquisition' and 'private use' naturally exclude each other: material which has been produced and possessed by children solely for their private use cannot be up for acquisition at the same time. Interesting is that in contrast to the Lanzarote Convention, the Directive adds an additional element pertaining to the recorded act, stating that the acts shall not involve any abuse. Further, the use of the term 'persons' instead of 'children' with regards to the private use clarifies that the material can be produced and possessed by adults, as long as the other elements of the exemption clause are fulfilled.

\section{Criminal Code Amendment}

The 2015 Criminal Code Amendment aimed at aligning German legislation with the Lanzarote Convention and the Directive. ${ }^{135}$ As the 2008 version of the juvenile pornography provision, ${ }^{136}$ the 2015 Criminal Code amendment also included an exemption clause:

'Subsection 1 Nr. 3 [production], also in conjunction with subsection 5 [attempt], and subsection 3 [possession and obtaining possession] shall not apply to acts of persons with regards to such juvenile pornography, which they produced solely for their private use with the consent of the depicted persons.'

This exemption clause aims to address some of the flaws of the 2008 amendment. While it does not only exempt the possession, but also the production of juvenile pornography, it is not required that the material was produced by persons under the age of eighteen years, as it was required under the 2008 exemption clause. ${ }^{137}$ The latter aimed to address situations whereby the consensual production of a 17-year-old and 18 -year-old was criminalised. ${ }^{138}$ It remains problematic that only persons who produce the material fall under the exemption clause. It is however commonly agreed that the person who is depicted in the material can also possess the material, even if he or

135 BT-Dr 18/2601, p. 1.

136 With the 2008 criminal code amendment, the government detached the child pornography provisions from the depiction of sexual abuse, and also included a new section $184 \mathrm{c}$, which criminalised juvenile pornography, depicting children between 14 and 17 years inclusively (BT-Dr 625/06 p. 11). Acknowledging that material consensually developed by teenagers cannot be treated equally to other forms of child and juvenile pornography (BTDr 625/06 p. 11.), the draft amendment in its final version included an exemption clause in section $184 \mathrm{c}$, modelled after Art 3 (2) (b) of the 2003 framework decision: 'The 1st sentence [obtaining possession of juvenile pornography] shall not apply to acts of persons related to juvenile pornography produced by them while under eighteen years of age and with the consent of the persons therein depicted.'.

137 Tatjana Hörnle in: Münchener Kommentar zum Strafgesetzbuch, § 184 c, para. 18 - 20.

138 BT-Dr 18/3202, p. 24. 
she was not involved in the production. ${ }^{139}$ The same teleological reduction should apply if a person possesses material which was solely produced by another person and solely depicts the producer, ${ }^{140}$ e.g. one partner possesses a 'selfie' of the other.

\section{Assessment}

As mentioned above, the sole exemption of the producer of the material, despite the proposed teleological interpretation, remains a concern. Further, assuming that the purpose of the child and juvenile pornography provision is to protect children from sexual abuse, it is only consequent to ensure that these provisions are aligned with the other provisions addressing sexual activity with children. ${ }^{141}$ German law provides for a complex system of age limits with regards to sexual interactions. While any sexual interaction with a child below the age of 14 years is prohibited, ${ }^{142}$ sexual activity with $14-17$-year-old adolescents is generally legal. However, there are various exceptions to that rule. With regards to the age group of 14 and 15 years old adolescents, the sexual activity is illegal if the adolescent is entrusted to the perpetrator for educational or caretaking purposes, ${ }^{143}$ or if a perpetrator who is above the age of 21 years, takes advantage of the adolescent's lack of sexual self-determination. ${ }^{144}$ With regards to adolescents between the age of 16 and 17 years, sexual activity is illegal e.g. if the perpetrator takes advantage of the adolescent's dire straits, ${ }^{145}$ or if the adolescent obtains some form of reward for the sexual activity. ${ }^{146}$

While this complex system aims to protect children from any form of sexual abuse and exploitation, it is surprising that the exemption clause with regards to juvenile pornography merely requires the consent of the adolescent, regardless how or under which circumstances such consent was obtained. While for example the sexual activity of a 15-year-old learner with his or her 35-year-old teacher - regardless of the adolescent's consent - amounts to a criminal offence, ${ }^{147}$ the production of juvenile pornography material between these two actors falls under the exemption clause, as long as the adolescent gives consent. Even though it can be assumed that a teleological interpretation of the exemption clause in such a case would result in its inapplicability to avoid inconsistencies within the legal framework, the wording alone does not consider exploitative relationships as invalidating an adolescent's consent. As a result, adolescents who engage in production and possession of juvenile pornography might be less protected than adolescents who engage in contact sexual activity with the same partner. On the other hand, this inconsistency might be intentional, and could be explained with a lower encroachment threshold: as the impact of actual sexual inter-

139 Tatjana Hörnle in: Münchener Kommentar zum Strafgesetzbuch, § 184 c, para. 18 - 20.

140 Ibid.

141 Helmut Baier, Die Bekämpfung der Kinderpornographie auf der Ebene von Europäischer Union und Europarat, Zeitschrift für Urheber- und Medienrecht, 2004, p. 45.

142 See $\S 176$ (1) Criminal Code.

143 See $\$ 174$ (1) Criminal Code.

144 See $\$ 182$ (3) Criminal Code.

145 See $§ 182$ (1) Criminal Code.

146 See $\$ 182$ (2) Criminal Code.

147 See $\S 174$ (1) 1. Criminal Code (sexual abuse of wards). 
actions is potentially more harmful to the adolescent, it might justify that in the area of juvenile pornography, the adolescent enjoys more sexual autonomy. In the abovementioned case, this means that the 15-year-old learner and the 35-year-old teacher can legally produce and possess juvenile pornography, while sexual acts in this constellation remain illegal.

Further, the exemption clause does not speak about the consensual or lawful underlying sexual activity. It is submitted that when consenting to the recording of the sexual activity, a person also consents to the recorded sexual activity. However, this constellation undermines the complex system of age of consent under German law, because only consent to both the recording and the recorded activity is required. This leaves out potential exploitative facts which influenced the teenager's consent in the first place.

In conclusion, the German exemption clause, despite going into the right direction, is erroneous in some areas. Apart from the inconsistency with the legal framework on contact sexual activity, the continuous criminalisation of selfies through sole protection of the producer, even if the possessed image is a depiction of the possessor himor herself, raises serious constitutional concerns with regards to the principle of legal certainty as well as the right to sexual self-determination. ${ }^{148}$

\section{Regulating bodies: balancing autonomy and protection}

The experiences from USA, Canada and Germany are proof of the complexity of the issues at hand. This section will first discuss whether consensual teenage sexting should be exempted from child pornography offences, and if, which elements should constitute such an exemption clause.

\section{A. A model for a rights-based approach to teenage sexuality: the South African Teddy Bear Clinic case}

Regardless of the result of the specific teenage sexting discussions, it is striking that most debates are fought in a legal vacuum detached from a rights-based approach. Apart from Sharpe and Barabash, which mention freedom of expression and a 'right to document' in their deliberations, it is surprising that the teenage sexting debate is mainly conducted from a child protection, rather than a child rights angle.

148 Henning Ernst Müller, Gesetzgeberischer Murks - der geplante § 184 c StGB (Jugendpornografie, beck-blog, 18 September 2014, https://community.beck.de/2014/09/18/gesetzgeberischer-murks-der-geplante-184c-stgb-jugendpornografie [Accessed 24 October 2018]; the principle of legal certainty can be derived from Art 20 III German Constitution ('Grundgesetz'); the right to sexual self-determination has been developed as part of the right to informational self-determination, Art 1 in conjunction with Art 2 (1) German Constitution; for an in-depth discussion of the term 'sexual self-determination' under German criminal law, see Tatjana Hörnle, Sexuelle Selbstbestimmung: Bedeutung, Voraussetzungen und kriminalpolitische Forderungen, Zeitschrift für die gesamte Strafrechtswissenschaft (2015), pp. $851-887$. 
It is crucial to stress that regulation of teenage sexting infringes upon such teenager's most private sphere (sexuality) and hence the criminalisation of such behaviour necessarily needs to be discussed within the realm of child rights, such as freedom of expression, right to privacy or other rights dealing with a person's sexuality or sexual expression. The key question is hence whether this extends to a right for minors to record and document their own lawful sexual activities, in particular, sexual conduct and nudity, and consensually share and possess this content. Which right is most suitable to serve as defence mechanism in such cases and how exactly various level of infringement can be justified and on which grounds goes beyond the scope of this publication. Rather, it is submitted, that any form of regulation, whether criminal or other, that infringes upon a child's private sphere has to be discussed in the context of a rights-based approach.

Taking a rights-based approach in the context of children, however, also means to take the rightsholder's limitations and hence need for protection into account. This means to pay close attention that sexual autonomy does not always equal consent. ${ }^{149}$ This is in particular relevant where power relationships, relationships of trust or dynamics of authority come into play, as children tend to be specifically vulnerable to such influences due to their developing capacity. This is the reason why laws in many countries do not only criminalise sexual activity with children under a certain age, but often times limit the validity of given consent in situations where there is a risk that consent is not given entirely voluntarily (e.g. relationship of dependence between child and the other person, or difference in age). Therefore, the child protection lens with regards to potential vulnerability needs to be applied within the context of child's rights, not vice versa.

When looking for a rights-based approach to teenage sexuality, the South African Constitutional Court case Teddy Bear Clinic for Abused Children and Another v Minister of Justice and Constitutional Development and Another, [2013] ZACC 35 (hereafter: Teddy Bear Clinic) comes to mind. Remarkable in this case are already the introductory remarks, as they clearly divert issues of morality around teenage sexuality from the problem at hand:

'At the outset it is important to emphasise what this is not about. It is not about whether children should or should not engage in sexual conduct. [...] Rather we are concerned with far narrower issue: whether it is constitutionally permissible for children to be subject to criminal sanctions in order to deter early sexual intimacy and combat the risks associated herewith. ${ }^{150}$

In this case, the Court had to decide whether provisions in the Sexual Offences Act, which criminalised consensual sexual acts with children between 12 and 16 years, were unconstitutional. ${ }^{151}$ If two children in that age group engaged in consensual sexual activity, they were both prosecuted, and held guilty for statutorily raping the

149 For an in-depth discussion of the concepts of sexual autonomy and consent, see Joseph J. Fischel/Hillary O'Connell, Disabling consent, or reconstructing sexual autonomy, Columbia Journal of Gender and Law, Volume 30/2 (2015).

150 Teddy Bear Clinic for Abused Children and Another v Minister of Justice and Constitutional Development and Another, [2013] ZACC 35, para. 3.

151 Ibid., para. 11. 
other. ${ }^{152}$ Further, the situation was aggravated by the establishment of the national sex offender registry as well as the mandatory reporting requirements for caregivers. ${ }^{153}$ The applicants in Teddy Bear Clinic argued that such criminalisation has various harmful effect on the child, such as exposure to the criminal justice system, and will have a negative effect on the child's understanding of, and healthy attitudes towards, sexuality. ${ }^{154}$ In conclusion, the provisions infringe upon a range of children's constitutional rights, such as human dignity, privacy, bodily and psychological dignity, as well as the best interests of the child principle. ${ }^{155}$ This infringement can further not be justified as there is no correlation between the limitations and the purpose they aim to achieve. ${ }^{156}$ In contrast, the respondents argued that the provisions did not infringe upon the child's rights, but rather advanced and protected those rights by delaying the choice to engage in consensual sexual activities. ${ }^{157}$ Alternatively, the respondents argued that in case the Court finds that rights are infringed, there is no less restrictive means, and that the provisions have to be read in conjunction with the juvenile justice legislation. In this context, the measures will only be implemented after giving due consideration to the child's interest. 158

Before diving into the constitutional analysis, it is worthwhile to briefly elaborate on the expert evidence submitted by the applicants. The expert submission stated that the adolescent phase is a critical and transformative period with long lasting effects for shaping their adult lives. ${ }^{159}$ Children engage in a range of sexual activities, ranging from kissing to sexual intercourse. This exploration is healthy, as long as the person is emotionally ready and willing. Further, the experts stressed that the support by adults in children's lives is crucial to help them make healthy choices. If children do not have a safe environment within which they can discuss their sexual experiences and ask questions, they lack this guidance. ${ }^{160}$ With regards to the criminal provisions, the experts pointed out a range of negative social and psychological effects. Children will experience a mixture of shame, embarrassment, anger and regret, which may lead to a generally negative attitude towards sexual relations, and these feelings will have a chilling impact on their help-seeking behaviour. The criminal provisions therefore contribute to the silencing of children, which makes them more vulnerable to negative and risky behaviour and outcomes, in particular as caregivers and institutions are faced with the mandatory reporting obligation. ${ }^{161}$

In its analysis, the Court had to investigate whether any rights are limited by the impugned provisions, and if so, whether the limitations are reasonable and justifiable in an open and democratic society. Firstly, the Court stressed that children enjoy each of the fundamental rights in the Constitution which are granted to everyone as indivi-

152 Ibid., para. 21.

153 Ibid., para. $17-18$.

154 Ibid., para. 28.

155 Ibid., para. 29.

156 Ibid., para. 30.

157 Ibid., para. 31.

158 Ibid., para. 32.

159 Ibid., para. 44.

160 Ibid., para. 45.

161 Ibid., para. 47. 
dual bearers of rights. ${ }^{162}$ The Court then went on to establish that the right to human dignity was limited by the criminal provisions. It held that dignity recognises the inherent worth of all individuals, children's dignity rights are not dependent on the rights of their parents, and rights are also not held in abeyance until they reach a certain age. ${ }^{163}$ The criminalisation of consensual sexual conduct is a form of stigmatisation which is degrading and invasive; if one's consensual sexual choices are disrespected by society, one's innate sense of self-worth will be inevitably diminished. ${ }^{164}$ With regards to right to privacy, the Court stated that the constitution protects the inner sanctum of personhood, including family life and sexual preference. The way in which we give expression to our sexuality is at the core of this area of private intimacy: if in expressing our sexuality we act consensually and without harming one another, invasion of that space constitutes breach of privacy. ${ }^{165}$ This applies in equal force to consensual sexual conduct of adolescents and is exacerbated by the mandatory reporting requirements. ${ }^{166}$ Further, the South African Constitution recognises the best interests of the child both as a right as well as a guiding principle. ${ }^{167}$ Provisions or conduct which affect children in general need to be tested against this standard. ${ }^{168}$ The provisions in the Sexual Offences Act increase the risk of harm to children by driving sexual activity underground and cut off support structures, as well as creating an atmosphere in which adolescents do not freely discuss sexuality anymore. ${ }^{169}$ The effect of diversion or imprisonment are not in line with the requirement of growing up free from avoidable trauma. ${ }^{170}$ Even if a child is diverted from criminal justice system, he or she still has to face arrest and investigation, before being diverted. Lastly, the Court made a significant remark:

'Indeed, it strikes me as fundamentally irrational to state that adolescents do not have the capacity to make choices about their sexual activity, yet in the same breath to contend that they have the capacity to be held criminally liable for such choices. ${ }^{\prime 171}$

In the following limitation analysis, the Court accepted that the purpose of legislation is to discourage adolescents from prematurely engaging in consensual sexual conduct. ${ }^{172}$ With regards to the nature and the extent of the limitation, the Court regarded the provisions as deep encroachment. ${ }^{173}$ With regards to the relation between the limitation and statutory purpose, the respondents submitted that children will be deterred from engaging in sexual activity, and this will assist in controlling the effects of sexu-

162 Ibid., para. 38.

163 Ibid., para. 52.

164 Ibid., para. 55.

165 Ibid., para. 59.

166 Ibid., para. 60.

167 Ibid., para. 65.

168 Ibid., para. 69.

169 Ibid., para. 72.

170 Ibid., para. 74.

171 Ibid., para. 79.

172 Ibid., para. 81

173 Ibid., para. 82. 
al intercourse, like pregnancy and STDs. ${ }^{174}$ The Court did not buy into that narrative, and stated that there is lack of proof that the existence and enforcement of these provisions actually lead to the reduction of harm as promulgated by respondents. It rather followed the expert submission which stated that as a consequence of the criminalisation, sexual activity is driven underground, away from the guidance of parents. ${ }^{175}$ Further, the Court stated that the provisions could also deter children from reporting crimes such as rape, if they initially agreed to a sexual activity, but withdrew their consent in the process and were subsequently raped. In such a case, the child might not report the crime, as it was at risk of being prosecuted for the initial, consensual sexual activity. ${ }^{176}$ Therefore, the Court held that there is no rational link between the provisions and the stated purpose. ${ }^{177}$ Additionally elaborating on less restrictive means, the Court stresses that there is a variety of less restrictive means available to encourage adolescents to engage in a healthy and responsible sexual relationships, such as improving parent-child sexual communication as well as comprehensive sex education instead of abstinence-only or no sex education. ${ }^{178}$ In conclusion, the Court held that the provisions in the Sexual Offences Act criminalising the adolescents for engaging in consensual sexual conduct are unconstitutional. ${ }^{179}$

Acknowledging that the criminalisation of teenage sexuality touches upon the core of their rights, while considering specific vulnerabilities that teenagers face, the Court sets an example on the balancing of autonomy and protection. This decision should be formative for any legal approach to teenage sexting, as teenage sexting is a form of sexual exploration and teenage sexual activity, and hence similar considerations come into play. Taking a rights-based approach as set out in Teddy Bear Clinic as a starting point, the next section will discuss the value of the criminalisation of teenage sexting in the name of protection.

\section{B. Criminalisation in the name of protection - a twisted concept}

As the introductory remarks in Teddy Bear Clinic stated, the Court intentionally tried to discuss the issue at hand detached from any moral assessment of whether children should have sex or not. However, when it comes to teenage sexting, the debate seems to be overshadowed by broader concerns around child sexuality, child sexual abuse and exploitation as well as new forms of technology.

Like the dissenting opinion in Sharpe, scholars have argued in favour of a criminalisation of teenage sexting, either as child pornography offence or as separate, more lenient criminal offence. The arguments for such criminalisation range from the limited value of the expression, the risks related to teenage sexting, to the deterrent effect

174 Ibid., para. $85-86$.

175 Ibid., para. 87.

176 Ibid., para. 93.

177 Ibid., para. 94.

178 Ibid., para. $98-99$.

179 Ibid., para. 101. 
of such legislation. ${ }^{180}$ When setting out these arguments, the language used usually describes the child as an innocent being, who must at all costs be protected against premature 'sexualisation', and hence reveals an 'angel/devil dichotomy' underlying these arguments. ${ }^{181}$ And if a child dares to break out of this label, he or she faces severe consequences. ${ }^{182}$ Additionally, girls face the consequences of a 'virgin/whore dichotomy', as they are not supposed to have any sexual desire in the first place. ${ }^{183}$ Children, and in particular girls, are hence deprived of any sexuality, let alone a right to express such sexuality, and seem to be only granted a right to protection from sexual exploitation. ${ }^{184}$ This approach is - again - in particular oppressive for girls, as it continues the old narrative that the only way to keep girls save is to exclude them from the platforms of participation. ${ }^{185}$

These underlying dynamics seem to be the true cause for the urge to criminalise consensual teenage sexting. This is not surprising, as the unresolvable contradictions in the legal framework caused by such a criminalisation cannot seriously be untangled on a technical basis. Firstly, it seems rather obvious that it is a twisted concept that the law turns the same person it intends to protect into the offender, in order to - again protect that same person. This would mean that the depicted person is simultaneously the victim and the perpetrator. ${ }^{186}$

Further, as pointed out in Teddy Bear Clinic, it is contradictory that a child is considered to be mature enough to have criminal capacity, while at the same time considered not mature enough to decide whether to engage in sexual activity. In fact, it is more in line with child development concerns to set a higher age of criminal responsibility and lower age of consent to sexual activity. Comparing criminal liability and consent to sexual activity, there are different questions the child needs to answer: Do I know what is right and wrong and am I capable of seeing the consequences of my actions? Or: Am I capable of giving informed consent to an action which will have no legal consequences? The best interests of the child principle requires us to take an ap-

180 See for example the arguments put forward in Megan Sherman, Sixteen, Sexting, and a Sex Offender: How Advances in Cell Phone Technology Have Led to Teenage Sex Offenders, Boston University Journal for Science and Technology Law, Vol. 17 (2011), pp. 157 - 158; Mary Graw Leary, Self-Produced Child Pornography: The Appropriate Societal Response to Juvenile Self-Sexual Exploitation, Virginia Journal of Social Policy and Law, Vol. 15 (2008), p. 39.

181 Dana Northcraft, A Nation Scared: Children, Sex and the Denial of Humanity, American University Journal of Gender, Social Policy \& the Law, Vol. 12 (2004), p. 511; applying Freud's theory of sexuality to argue that the motives behind the criminalisation of sexting might actually be the expansion of the latency phase, Matthew H. Birkhold, Freud on the Court: Re-interpreting Sexting \& Child Pornography Laws, Fordham Intellectual Proper-

182 Ibid. ty, Media \& Entertainment Law Journal, Vol. 23 (2013).

183 Northcraft, A Nation Scared: Children, Sex and the Denial of Humanity, American University Journal of Gender, Social Policy \& the Law, p. 512.

184 Carpenter/ O’Brien/ Hayes/Death, Harm, Responsibility, Age, and Consent, New Criminal Law Review: An International and Interdisciplinary Journal, p. 31.

185 Laurie Penny, Unspeakable Things, Bloomsbury 2014, p. 165.

186 Jamie L. Williams, Teens, Sexts, \& Cyberspace: The Constitutional Implications of Current Sexting \& Cyberbullying Laws, William and Mary Bill of Rights Journal, Vol. 20 (2012), p. 1032. 
proach which ensure the safety and wellbeing of children, and weigh our judgement against this objective. Even though both decisions, engaging in criminal conduct or in sexual activity, might be mainly emotional and impulsive ones, more maturity should be required from a child with regards to criminal liability, as the child needs to assess the legal consequences of his or her behaviour. Therefore, it is contradictory and not in the best interests of the child to assume that a child lacks the capacity to consent to sexual activity, but has criminal capacity.

When debating consensual sexting between minors, it is remarkable that this phenomenon is primarily discussed in the realm of child pornography. While child pornography and teenage sexting have merely the material depicting sexual activity of children in common, their underlying dynamics are fundamentally different. Child pornography depicts child sexual abuse and exploitation, and teenage sexting depicts consensual sexual activity of teenagers. It is therefore submitted that as starting point, we need to rethink the reference point for assessing teenage sexting. Teenage sexting should be discussed in the broader context of sexual activity of teenagers, as it is just another form of teenage sexual activity. As much as sexualised violence is a potential risk for teenagers engaging in sexual activity, child pornography is a risk for teenagers engaging in sexting.

Taking the sexual activity of teenagers as a starting point and building on the rightsbased approach in Teddy Bear Clinic, the question arises whether any arguments could justify a different assessment of teenage sexting in contrast to contact sexual activity. When comparing the risk of sexualised violence, pregnancy and STD's inherent to contact sexual activity with the risk of dissemination of material against the will of the depicted person, it is clear that the latter risks cannot be considered more intrusive to a teenager's life (rather the opposite!). Further, the criminalisation of teenage sexting might lead to the same negative effects as the criminalisation of sexual activity between teenagers discussed in Teddy Bear Clinic: teenage sexuality is driven underground, parental guidance to safe sexting is hampered, and teenagers will not seek support if material is disseminated against their will.

The criminalisation of consensual sexting between minors is hence counterproductive at any level. It is therefore submitted that consensual teenage sexting needs to be excluded from child pornography provisions. The necessary elements of such an exemption clause are discussed below.

\section{Elements of an exemption clause}

The exemption clauses provided for in Sharpe, the Lanzarote Convention, EU Directive and German legislation differ, and hence provide for contrasting levels of protection for minors engaged in sexting. This section aims to provide guidance on the optimal elements of an exemption clause.

Firstly, with the exception of the EU directive, the exemption clauses decriminalise only the production and possession of teenage sexting material. The inclusion of any other actions should be avoided, as it might negatively expand the scope of the provision. Strictly speaking, if the distribution of teenage sexting material is not covered by the exemption clause, the material could never be shared with the partner, as this al- 
ways amounts to distribution. However, it is submitted that 'distribution' means the dissemination of material to an unknown number of recipients, and alternatively, that the 'distribution' between partners would be covered by applying a teleological interpretation of the terms 'possession' and 'production', as such a clause otherwise prevents any form of sharing and hence defeats its purpose.

Moreover, regarding the subjects of the exemption clause, it is clear that people who are either depicted in the recording or who have participated in its creation, should be included in an exemption clause. Furthermore, assuming that a wide range of teenage sexting material includes selfies, which are often times produced without any other person being present or participating, a person who consensually possesses such material and has received it from the depicted person, should enjoy the same level of protection, as anything else would just not reflect the reality of teenage sexting.

With regards to the interpretation of the term 'private use', reference is made to the deliberations regarding the broad interpretation of the term 'private use' in Dabrowski. Even if not interpreted in the strict sense of exclusive possession of the participant, the third party to which such protection is extended must be able to ensure highest level of confidentiality and have a legitimate reason for possession of such material.

Based on the interconnectedness of contact and digital sexual activity, the legislative framework should respond to these phenomena in unison: this requires an alignment of age of consent laws with any regulations regarding teenage sexting. Reiterating that the risk related to teenage sexting is equally likely to turn into harm compared to the risk related to contact sexual activity, there is no justification for treating these two forms of teenage sexual activity differently. Generally, the term 'lawful sexual activity' is preferred in contrast to 'consensual sexual activity', as the national framework might criminalise even consensual sexual activity with a minor if there is an exploitative relationship of any kind. If the national framework with regards to contact sexual activity only focuses on the consent of the child, regardless of any elements of abuse and exploitation, it might be useful to add an element of 'abuse and exploitation', to ensure children are sufficiently protected. However, this is rather a gap in the age of consent laws and should primarily be addressed on that level. As has been debated in Sharpe, the question arises whether with regards to the recording of the lawful sexual activity, mere consent is sufficient, or whether an additional element of 'lack of abuse and exploitation' should be added. One might argue that if a child consented to the sexual activity without any elements of abuse or exploitation present, there is no need for a distinct element with regards to the recording, as long as the child gives consent to the recording. However, it has to be noted that these elements are not always congruent: a teenager might be pressured into agreeing to a recording, while not being pressured into the recorded sexual activity. In absence of an additional element on the recording level, the described scenario might be protected by the exemption clause, even though the consent given to the recording was obtained in the context of an abusive or exploitative situation. Therefore, the recording itself should be consensual and that consent should have been obtained without any factors of abuse or exploitation present.

Finally, it seems plausible that - as pointed out in the obiter dictum in Barabash the exemption clause should only be applicable as long as all participants consent to 
the ongoing possession of all parties. However, this topic requires more in-depth research and consideration and hence exceeds the scope of this publication.

\section{Preventing risk from turning into harm in the digital space}

In conclusion, the criminalisation of consensual sexting between minors is not the right instrument to prevent risk turning into harm. Even though criminal law seems often times to be the least complex (or most comfortable?) solution, and assuming that in the majority of cases the aim of such intervention is truly to protect children from any form of abuse and exploitation, the generational digital divide might significantly contribute to the moral panic around digital sexual exploration of children. As digital sexual exploration is a fairly alien concept for the older generation, they might not understand why teenagers engage in such behaviour in the first place. This lack of understanding with regards to the underlying dynamics might solicit the overreaction and result in a blurred concept of risk and harm.

One of the key interventions to ensure that risk does not turn into harm is the capacitation of children to detect risks and give them tools how to respond to them. This can be achieved through comprehensive sexuality education, focusing on gender stereotypes, sexual autonomy, and building healthy sexual relationships with oneself and others, both online and offline. At the same time, creating a safe and confidential environment for questions around sexuality and sexual exploration, in schools, homes and the community, could assist in promoting safer sex(ting). As these interventions are not a quick fix but require long term investments in the education and social welfare sector, they might be less popular than just criminalising such behaviour. Or, with the words of Laurie Penny: 'The scourge of the underage slags must be stamped out by any means necessary, as long as those means don't involve actually providing useful sex education. ${ }^{\prime 187}$

187 Laurie Penny, Teenage girls and the pill, New Statesman America, 2 November 2010, https://www.newstatesman.com/blogs/laurie-penny/2010/11/young-girls-sex-access-pill [Accessed on 3 October 2018]. 